\title{
Crow Sagacity
}

By H. M. RAYNER, Ituna, Sask.

$\mathbf{O}^{\mathrm{N}}$ N JULY 19th of this year, in the course of a three-mile walk in the country, I saw several families of young crows nearly full grown, and quickly learning the nonchalant independence that is characteristic of crows. Your adult sophisticated crow combines wisdom and ruthlessness with the devil-may-care swagger of a successful pirate. $\mathrm{He}$ is a sort of Long John Silver in the bir.d world.

Two young crows, perched on the topmost branch of a small poplar tree, promised interesting watching. They had not long left the nest, and one of the parent birds perching beside them, mounted guard.

The other parent was away in search of food. The guarding crow at intervals extended its lungs with a lusty caw-caw-caw, and from far in the distance I could hear the answering call of its foraging mate. The answers began to grow louder. Plainly the cruising crow was coming back with provender. The tree in question crowned a knoll of high prairie. Lush glass, with mingling gaillardia, harebells and wild ilax, adorned its pleasant slopes. I sat down to enjoy the flowers and watch the crows.

Seconds later, a couple of gaping throats welcomed the provider. What he brought I could not see, and it was scon stuffed out of sight into one of the youngsters. Only one was fed, indicating that the rule was turn about.

The tree the crows were perched in was not more than 12 or 14 feet high. Farther down, the northern slope of the hill was wooded with a growth of older and taller trees, standing in a nearly impenetrable uiidergrowth of hazel-nut and peavine. Curious to see what the old crows would do about it, I got up and began walking towards them.

The old crows took wing and began circling the tree with much excited caw-cawing. They were trying to alarm the youngsters and draw them off. The youngsters lacked confidence in their powers of flight, and were more afraid of taking to the air than of danger from me.

Then one of them took wing. One parent flew after it, and saw it safely berthed in one of the taller trees. The other continued circling and coaxing the tardy youngster to follow his more courageous nest-mate. He stuck stubbornly to his perch. I advanced still closer. This was more than the old crow could stand for. Down she swept at full speed. Levelling out, she hit the young one squarely with her breast, and knocked him out of the tree like a nine-pin. One hears about being "knocked flying." That young crow quite literally was.

Once launched into the abyss, he flapped for his life, and managed to make it to the nearest of the tall trees. I went on my way, well rewarded for my time by this demonstration of crow sagacity.

\section{Pheasants at Elfros}

\section{GLADYS STITTLE}

Pheasants were seen in this district (eight miles south of Elfros) for the first time last October 25. My brothers were driving along the road, about three quarters of a mile from home, when the dog chased up a bird. It flew towards them, and as it was quite near, they saw that it had a very long tail, so instantly knew it was none other than that beautifully colcred bird, the Pheasant.

The tail, wings and body were rufus, speckled with black. The neck was green and around the eye was a rusty red, but the colors weren't as bright as in some pictures we have seen. We thought that this was due to their taking on colorings in the fall to blend with their surroundings as a protection against their enemies. If seen in the spring at mating time they have brighter colors.

Another Pheasant was seen only a mile from where the other one was found, so we are hoping they may increase in this district. 